\title{
The roles of vertical advection and eddy diffusion in the equatorial mesospheric semi-annual oscillation (MSAO)
}

\author{
R. L. Gattinger ${ }^{1}$, E. Kyrölä ${ }^{2}$, C. D. Boone ${ }^{3}$, W. F. J. Evans ${ }^{4,5}$, K. A. Walker ${ }^{6,3}$, I. C. McDade ${ }^{7}$, P. F. Bernath ${ }^{8,3}$, and \\ E. J. Llewellyn ${ }^{1}$ \\ ${ }^{1}$ ISAS, Department of Physics and Engineering Physics, 116 Science Place, University of Saskatchewan, \\ Saskatoon SK, S7N 5E2, Canada \\ ${ }^{2}$ Finnish Meteorological Institute, Earth Observation, P.O. Box 503, 00101, Helsinki, Finland \\ ${ }^{3}$ Department of Chemistry, University of Waterloo, Waterloo, ON, N2L 3G1, Canada \\ ${ }^{4}$ NorthWest Research Associates Inc., 4118148 Avenue N.E., Redmond, WA 98052, USA \\ ${ }^{5}$ Centre for Research in Earth and Space Science (CRESS), York University, 4700 Keele Street, Toronto, \\ ON, M3J 1P3, Canada \\ ${ }^{6}$ Department of Physics, University of Toronto, 60 St. George Street, Toronto, ON, M5S 1A7, Canada \\ ${ }^{7}$ Department of Earth and Space Science and Engineering (ESSE), York University, 4700 Keele Street, Toronto, \\ ON, M3J 1P3, Canada \\ ${ }^{8}$ Department of Chemistry and Biochemistry, Old Dominion University, 4541 Hampton Boulevard, Norfolk, \\ Virginia 23529-0126, USA
}

Correspondence to: E. J. Llewellyn (edward.llewellyn@usask.ca)

Received: 18 September 2012 - Published in Atmos. Chem. Phys. Discuss.: 9 January 2013

Revised: 15 May 2013 - Accepted: 5 July 2013 - Published: 14 August 2013

\begin{abstract}
Observations of the mesospheric semi-annual oscillation (MSAO) in the equatorial region have been reported dating back several decades. Seasonal variations in both species densities and airglow emissions are well documented. The extensive observations available offer an excellent case study for comparison with model simulations. A broad range of MSAO measurements is summarised with emphasis on the $80-100 \mathrm{~km}$ region. The objective here is not to address directly the complicated driving forces of the MSAO, but rather to employ a combination of observations and model simulations to estimate the limits of some of the underlying dynamical processes. Photochemical model simulations are included for near-equinox and near-solstice conditions, the two times with notable differences in the observed MSAO parameters. Diurnal tides are incorporated in the model to facilitate comparisons of observations made at different local times. The roles of water vapour as the "driver" species and ozone as the "response" species are examined to test for consistency between the model results and observations. The simulations suggest the interactions between vertical eddy diffusion and background vertical ad-
\end{abstract}

vection play a significant role in the MSAO phenomenon. Further, the simulations imply there are rigid limits on vertical advection rates and eddy diffusion rates. For August at the Equator, $90 \mathrm{~km}$ altitude, the derived eddy diffusion rate is approximately $1 \times 10^{6} \mathrm{~cm}^{2} \mathrm{~s}^{-1}$ and the vertical advection is upwards at $0.8 \mathrm{~cm} \mathrm{~s}^{-1}$. For April the corresponding values are $4 \times 10^{5} \mathrm{~cm}^{2} \mathrm{~s}^{-1}$ and $0.1 \mathrm{~cm} \mathrm{~s}^{-1}$. These results from the current 1-D model simulations will need to be verified by a full 3-D simulation. Exactly how vertical advection and eddy diffusion are related to gravity wave momentum as discussed by Dunkerton (1982) three decades ago remains to be addressed.

\section{Introduction}

Observations of the mesospheric semi-annual oscillation (MSAO) in equatorial airglow emissions have been documented dating back several decades, for example the groundbased data of Fukuyama (1977) who observed seasonal variations in OI $5577 \AA(\mathrm{OI})$, in the hydroxyl $\left(\mathrm{OH}^{*}\right)$ and sodium 
$\left(\mathrm{Na}^{*}\right)$ airglow emissions at low-latitude stations. Cogger et al. (1981) observed a pronounced seasonal variation in the ISIS OI airglow data. Burrage et al. (1994) found a persistent seasonal variation in the $\mathrm{O}_{2}$ Atmospheric $\mathrm{A}$ band $\left(\mathrm{O}_{2} \mathrm{~A}\right)$ using the UARS/HRDI (High Resolution Doppler Imager) instrument, the brightness being well correlated with the horizontal meridional wind field. A more recent example is that of Shepherd et al. (2006) using data from the UARS/WINDII (WIND Imaging Interferometer) instrument covering the period from 1992 through 1995. They found a recurring seasonal variation in nighttime $\mathrm{OI}$ centred on $96 \mathrm{~km}$ and in $\mathrm{OH}^{*}$ centred on $87 \mathrm{~km}$, the maxima being at the equinox periods. Observations by Skinner et al. (1998), also using the UARS/HRDI instrument, showed very similar results.

The equatorial MSAO can also be seen in measurements of minor species in the $90 \mathrm{~km}$ altitude region. Thomas (1995) presented atomic hydrogen $(\mathrm{H})$ and atomic oxygen (O) climatologies that clearly showed the MSAO. Chandra et al. (1997) observed seasonal variations in water vapour $\left(\mathrm{H}_{2} \mathrm{O}\right)$ using UARS/MLS (Microwave Limb Sounder) and HALOE (HALogen Occultation Experiment) data and, in addition, obtained good agreement with a twodimensional (2-D) photochemical and transport model. Lossow et al. (2008), using sub-mm radiometer (SMR) data from the Odin spacecraft (Murtagh et al., 2002), observed the MSAO in $\mathrm{H}_{2} \mathrm{O}$ mixing ratio, the maxima at $90 \mathrm{~km}$ occurring in the solstice periods. Kyrölä et al. (2006, 2010), using Envisat/GOMOS (Global Ozone Monitoring by Occultation of Stars) data, found that ozone $\left(\mathrm{O}_{3}\right)$ at $90 \mathrm{~km}$ peaked in equinox periods and was approximately a factor of three lower in solstice periods. Huang et al. (2008) and Smith et al. (2008) found a similar variation in $\mathrm{O}_{3}$ using data from TIMED/SABER (Sounding of the Atmosphere using Broadband Emission Radiometry). Seasonal oscillations in mesospheric atomic oxygen $(\mathrm{O})$ were inferred by Sheese et al. (2011) using observations from OSIRIS (Optical Spectrograph and InfraRed Imaging System) (Llewellyn et al., 2004) on Odin, and by Smith et al. (2010) using TIMED/SABER data. Both of these $\mathrm{O}$ studies also showed diurnal variations. The semi-annual oscillation at higher latitudes, not the focus of the current study, transitions into an annual oscillation (Thomas, 1990; Kyrölä et al., 2010).

Numerous model simulations of the MSAO driving forces have been published. Dunkerton (1982) originally suggested that the MSAO was driven from below by gravity wave momentum. Easterly and westerly phase speed waves are selectively transmitted through the semi-annually varying stratopause wind phases. Richter and Garcia (2006) evaluated the relative importance of the various MSAO forcing terms included in WACCM2 (Whole Atmosphere Community Climate Model) and concluded that at solstice the mechanism proposed by Dunkerton is the dominant source of the strong mesospheric westerlies, but there are opposing easterlies driven by meridional advection. However, they found that at equinox the MSAO easterlies are not satisfactorily simulated by the WACCM2 model. Richter et al. (2008), using WACCM3, addressed the complex interaction between gravity waves and horizontal winds and again pointed out the model limitations. Alexander et al. (2010) provided an extensive review of gravity wave observations and associated model parameterisations and discussed the agreements, and disparities, between model predictions and observations. In summary, differences between model simulations and MSAO observations are not yet adequately explained.

The following sections contain comparisons between simulations using a time-dependent one-dimensional (1-D) photochemical model and observations from various sources. The focus here is intentionally limited to addressing the observed MSAO in the equatorial region. Diurnal tides, eddy diffusion and the prevailing background vertical winds make up the dynamic components included in the 1-D model. More detailed examples of such combined photochemical and dynamical model comparisons with observations are those of Marsh et al. (2003), Smith and Marsh (2005) based on the ROSE model, Wu et al. (2008) with the TIME-GCM model, and Dikty et al. (2010) using the HAMMONIA model.

The diurnal tides (Hagan et al., 1999) are necessarily included in the model as they have a significant impact on instantaneous measurements of minor species densities and airglow emissions (Smith, 2004), particularly in the equatorial mesosphere. Yee et al. (1997) demonstrated the effects of diurnal tides in their extensive model simulations of the UARS/HRDI observations. Smith et al. (2010) have also successfully simulated the significant diurnal tidal effects in the O observations made with SABER. Studies by Wu et al. (2008) and John and Kumar (2011) provide further insight into the details of the tides. Again, when comparing observations made at different local times the tidal effect must be considered. Conversely, observations of selected species made at differing local times can be used to validate model simulations of the diurnal tides.

Eddy diffusion also has a significant impact on the vertical distribution of mesospheric minor species. Instances of such studies are those of Vlasov and Kelley (2010) for the effects of turbulence on the $\mathrm{O}$ vertical profile, and similarly by Sonnemann and Körner (2003) for the H profile. The seasonal variation of eddy diffusion at low latitude, the target latitude for the current study, was derived from mesospherestratosphere-troposphere (MST) radar observations by Sasi and Vijayan (2001), with maximum turbulence observed at solstice periods. Seasonal variations of eddy diffusion have also been inferred by Liu (2009) for mid-latitudes and by Hall et al. (1999) at high latitudes, potentially providing realistic constraints for future studies.

The present objective is not to address directly the complicated driving forces of the MSAO but rather to employ a combination of observations, in particular the measured vertical profiles of ozone and water vapour, in conjunction with model simulations to estimate the limits of two of the dynamical processes, namely vertical eddy diffusion rates and 
background vertical winds. The model "solution" entails adjusting both the vertical background wind and vertical eddy diffusion rates until the model ozone and water vapour vertical profiles match the observed ozone and water profiles. The rationale for the final choice of the observed seasonal variations of ozone and water vapour vertical profiles is discussed. The validity of these two "input constraints" is crucial to achieving the objective of determining the eddy diffusion rate and the vertical background wind. Two simulation periods are discussed, one for near-equinox conditions and one for near-solstice conditions, that is, the two extremes of the MSAO phenomenon. As an independent check on the MSAO model simulations the seasonal variation of model airglow emissions is compared against observed variations.

\section{MSAO data driving the model simulation}

As mentioned above, knowledge of the seasonal variation of the $\mathrm{H}_{2} \mathrm{O}$ mixing ratio in the equatorial $90 \mathrm{~km}$ region is fundamental to the current study. Various observations are compared here and their merits briefly discussed. A strong equatorial MSAO was observed in the $\mathrm{H}_{2} \mathrm{O}$ mixing ratio by Lossow et al. (2008) with the $90 \mathrm{~km}$ mixing ratio varying from approximately $0.1 \mathrm{ppm}$ in April to approximately $0.4 \mathrm{ppm}$ in July. The upper altitude limit of their published profiles is $100 \mathrm{~km}$. Considerable averaging over many individual limb profiles was required in order to achieve the published height profiles. A similar equatorial seasonal variation was observed in the $\mathrm{H}_{2} \mathrm{O}$ profiles measured with the MLS instrument on the Aura spacecraft (McCormack et al., 2008). At solstice the Aura group recommended an $\mathrm{H}_{2} \mathrm{O}$ mixing ratio at $90 \mathrm{~km}$ of approximately $1 \mathrm{ppm}$. The upper altitude limit of the $\mathrm{H}_{2} \mathrm{O}$ Aura observations being approximately $90 \mathrm{~km}$ suggests caution in using the Aura results as the input for the current $90 \mathrm{~km}$ simulations. Equatorial observations of the MSAO in $\mathrm{H}_{2} \mathrm{O}$ were also obtained with the ACE-FTS (Fourier Transform Spectrometer) instrument on SCISAT (Bernath et al., 2005). They observed the mixing ratio to increase from approximately $0.1 \mathrm{ppm}$ at $90 \mathrm{~km}$ in April to approximately $0.6 \mathrm{ppm}$ in August. The ACE-FTS observations, in solar occultation, extend to approximately one scale height above $90 \mathrm{~km}$, with single profile measurement accuracy at $90 \mathrm{~km}$ exceeding that of the other two measurements referenced above. In the current study the equatorial MSAO in $\mathrm{H}_{2} \mathrm{O}$ is taken from the ACE-FTS observations. This represents a compromise amongst the three results referenced here. For the model initial conditions the ACE-FTS $\mathrm{H}_{2} \mathrm{O}$ profiles from approximately $15^{\circ} \mathrm{N}$ to $15^{\circ} \mathrm{S}$ are averaged over approximately 5 days, that is, the time it takes for the ACEFTS observations to traverse that latitude range. Since the simulation here is based on a 1-D model, the effects of latitudinal gradients are not included in the model. For the range from 15 to $30^{\circ} \mathrm{S}$ the average ACE-FTS $\mathrm{H}_{2} \mathrm{O}$ mixing ratio for April, at $90 \mathrm{~km}$ altitude, is approximately $0.1 \mathrm{ppm}$, the same as in the region spanning the Equator. For $15-30^{\circ} \mathrm{N}$ the average is approximately $0.13 \mathrm{ppm}$. These measured changes with latitude do not significantly affect the final conclusions.

For the seasonal variation of the $\mathrm{O}_{3}$ profiles in the upper mesosphere the chosen reference measurements are the nighttime observations of Kyrölä et al. $(2006,2010)$ made with the GOMOS instrument on Envisat. Their $\mathrm{O}_{3}$ profiles, based on a direct measurements of stellar occultation, extended to an upper altitude of approximately $100 \mathrm{~km}$. At $90 \mathrm{~km}$ the observed $\mathrm{O}_{3}$ density peaked in equinox periods and was approximately a factor of three lower in solstice periods. Since $\mathrm{O}_{3}$ is a short-lived species at $90 \mathrm{~km}$, relative to $\mathrm{O}$ and $\mathrm{H}$, and since nighttime $\mathrm{O}_{3}$ densities are driven by $\mathrm{O}$ and $\mathrm{H}$, and by temperature, $\mathrm{O}_{3}$ can also be used as a probe for the longer-lived $\mathrm{O}$ and $\mathrm{H}$ species.

The $\mathrm{H}$ profiles assumed in the model initial conditions were determined using data from Thomas (1990, 1995), who constructed a seasonal and latitudinal climatology for $\mathrm{H}$, as well as for $\mathrm{O}$, from the Solar Mesosphere Explorer (SME) observations. The SME equatorial $\mathrm{H}$ densities near the mesopause at solstice were approximately twice as large as at equinox. For similar conditions Xu et al. (2012) inferred an $\mathrm{H}$ seasonal variation of a factor of three using the SABER dataset. Sharp and Kita (1987) made a direct measurement of the $\mathrm{H}$ profile, but at mid-latitudes and so not as relevant for the present purposes. Ultimately, the model simulation of $\mathrm{H}$ is derived from the measured $\mathrm{H}_{2} \mathrm{O}$ profile combined with the solar photodissociation by Lyman- $\alpha$ with the input solar flux obtained from the LASP Solar Irradiance Data Center. Relating to mesospheric odd H species, Shapiro et al. (2012) documented the direct connection between ground-state hydroxyl $(\mathrm{OH})$ and $\mathrm{H}_{2} \mathrm{O}$ densities and the Lyman- $\alpha$ variation with the 27-day solar rotation cycle.

Seasonal variations of vertical profiles of $\mathrm{O}$ (Sheese et al., 2011) are also included in the model analysis as initial conditions with data from the OSIRIS instrument on Odin. The $\mathrm{O}$ densities are derived from observed $\mathrm{O}_{2}$ A-band vertical profiles following the method of McDade et al. (1986). The derived seasonal variations are similar to those observed by Thomas (1995) and by Xu et al. (2012).

The background atmosphere assumed in the simulation is based on the ACE-FTS measurements of temperature and density that are in general agreement with the NRL-MSISE00 model estimates by Picone et al. (2002). In the current work only two specific times are considered, April and August. These times sample approximately the maxima and the minima of the MSAO seasonal variation. The choices are driven by the times when the ACE-FTS limb occultations are transiting the equatorial region.

The eddy diffusion at equatorial latitudes is one of the derived parameters in this study. As an initial condition in the model the seasonal variation of eddy diffusion obtained from the MST radar results by Sasi and Vijayan (2001) was assumed. They observed a maximum in turbulence at solstice with an eddy diffusion rate of approximately 
$2 \times 10^{6} \mathrm{~cm}^{2} \mathrm{~s}^{-1}$ at $90 \mathrm{~km}$ altitude and a minimum of approximately $3 \times 10^{5} \mathrm{~cm}^{2} \mathrm{~s}^{-1}$ at equinox. Qian et al. (2009) adopted a very similar eddy diffusion pattern for the lower boundary of their TIE-GCM simulation of the seasonal variation of the thermosphere. Numerous model runs were conducted here with the eddy diffusion rate iteratively adjusted, in combination with adjustments to the vertical advection rate, until the model $\mathrm{H}_{2} \mathrm{O}$ and $\mathrm{O}_{3}$ profiles matched the observed profiles discussed above. As discussed in the following sections the observed values for eddy diffusion rates are similar to the final model-derived values of $4 \times 10^{5} \mathrm{~cm}^{2} \mathrm{~s}^{-1}$ for April and $1 \times 10^{6} \mathrm{~cm}^{2} \mathrm{~s}^{-1}$ for August, the values required to obtain the match.

The impact of vertical advection on species profiles is also included in the model. Beginning with an extensive horizontal wind model based on comprehensive observations Portnyagin et al. (2010) derived seasonal vertical wind profiles as a function of latitude. Their analysis was based on monthly means of zonally averaged meridional winds. For April in the equatorial region they inferred a prevailing downward wind of approximately $0.5 \mathrm{~cm} \mathrm{~s}^{-1}$ at $90 \mathrm{~km}$ altitude and for July a similar but upward wind. Unfortunately, their estimated errors for the derived vertical winds were of comparable magnitude. Richter and Garcia (2006, their Fig. 5), using WACCM2, inferred the equatorial upward advection for August to be larger than for April. Fauliot et al. (1997) derived equatorial prevailing vertical winds using UARS/WINDII data, the inferred values being in the range of $1 \mathrm{~cm} \mathrm{~s}^{-1}$. Chandra et al. (1997) found from their 2-D model that the $77 \mathrm{~km}$ altitude prevailing vertical winds at $45^{\circ} \mathrm{N}$ varied from approximately null in April to $0.5 \mathrm{~cm} \mathrm{~s}^{-1}$ upwards in August. The current model simulations also include the equatorial diurnal tides which exhibit an oscillating vertical component, in contrast to the prevailing vertical wind. According to Hagan et al. (1999) the tidal vertical wind amplitude for April is approximately $20 \%$ larger than for August. Based on the disparities amongst the various derived vertical advection rates it would appear that the actual values are very uncertain. For the model initial conditions a prevailing upward wind of $0.5 \mathrm{~cm} \mathrm{~s}^{-1}$ was arbitrarily assumed. Again, numerous model runs were conducted with the prevailing vertical wind iteratively adjusted, along with adjustments to eddy diffusion rates, until the model $\mathrm{H}_{2} \mathrm{O}$ and $\mathrm{O}_{3}$ profiles matched the observed profiles described above. From discussions in the following sections the final model prevailing vertical winds required are $0.1 \mathrm{~cm} \mathrm{~s}^{-1}$ upward in April and $0.8 \mathrm{~cm} \mathrm{~s}^{-1}$ upward in August.

The details of the model photochemistry and dynamics are briefly described below. Starting with the various initial conditions, diurnal simulations were conducted for the April near-equinox conditions and for August. Simulations were conducted over a period of ten model days to check for approximate convergence to a diurnally repeating steady state. Diurnal variations of the altitude profiles for a number of species for model days seven and eight are presented.
Interactions between photochemical effects and dynamical effects, including molecular diffusion, eddy diffusion and diurnal migrating tides, are explored.

\section{Simulations of the relevant species profiles}

As mentioned above the simulations are performed with a time-dependent 1-D model including photochemical and dynamical components tailored to the mesosphere and lower thermosphere. Time-varying solutions are obtained for $\mathrm{O}$, $\mathrm{O}_{3}, \mathrm{O}_{2}\left({ }^{1} \Delta\right), \mathrm{H}$, molecular hydrogen $\left(\mathrm{H}_{2}\right), \mathrm{H}_{2} \mathrm{O}, \mathrm{OH}$, perhydroxyl $\left(\mathrm{HO}_{2}\right)$, hydrogen peroxide $\left(\mathrm{H}_{2} \mathrm{O}_{2}\right)$, carbon monoxide $(\mathrm{CO})$ and carbon dioxide $\left(\mathrm{CO}_{2}\right)$. The underlying photochemical continuity equations are described in detail by Brasseur and Solomon (2005). Adopted reaction rates follow those given by Sander et al. (2011). Solar flux and photolysis cross sections cover the $116-725 \mathrm{~nm}$ spectral range. For water vapour and molecular oxygen particular attention is paid to the important roles played by solar radiation at Lyman$\alpha$ (Lewis et al., 1983; Chabrillat and Kockarts, 1997) and in the Schumann-Runge bands (Kockarts, 1994). Lyman- $\alpha$ flux values are obtained from the SORCE compilations. Diurnally varying photolysis rates are recalculated at $1^{\circ}$ solar elevation angle increments and at $1 \mathrm{~km}$ intervals throughout the model range. The numerical integration algorithms are designed to deal with the wide range of time constants exhibited by the mesospheric chemical reactions, from the fast catalytic recycling of $\mathrm{OH}_{x}$ in the removal of odd oxygen to the slow rate of odd hydrogen production and removal near the mesopause.

The continuity equations describing eddy diffusion and molecular diffusion are also provided by Brasseur and Solomon (2005). A tri-diagonal matrix formulation covering the altitude range is solved for the longer-lived species, namely $\mathrm{O}, \mathrm{H}, \mathrm{H}_{2}, \mathrm{H}_{2} \mathrm{O}, \mathrm{CO}$ and $\mathrm{CO}_{2}$. The thermospheric model results of Tian et al. (2008) are used as a check on the simulated $\mathrm{H}$ densities at the model upper boundary, in the $110 \mathrm{~km}$ range.

For the numerical simulation of vertical winds and diurnal tides the non-linear nature of atmospheric vertical distribution poses a problem. Holton (2004) and Brasseur and Solomon (2005) listed mathematical techniques that have been used, with partial success, to introduce vertical advection. Building on previous approaches, non-linear fitting methods for each species are employed in the current model to simulate vertical transport across layer intersections. Tests over periods longer than the 10-day simulation reported here were conducted to ensure residual numerical error propagation was less than a few percent. For the 1-D model the diurnal tidal phases and amplitudes for April and for August are from Hagan et al. (1999). The tides are included as both temperature oscillations and vertical wind oscillations.

As quoted above, from the simulations presented here, which are intended to provide agreement with the MSAO observations, the model-derived $90 \mathrm{~km}$ vertical eddy diffusion 


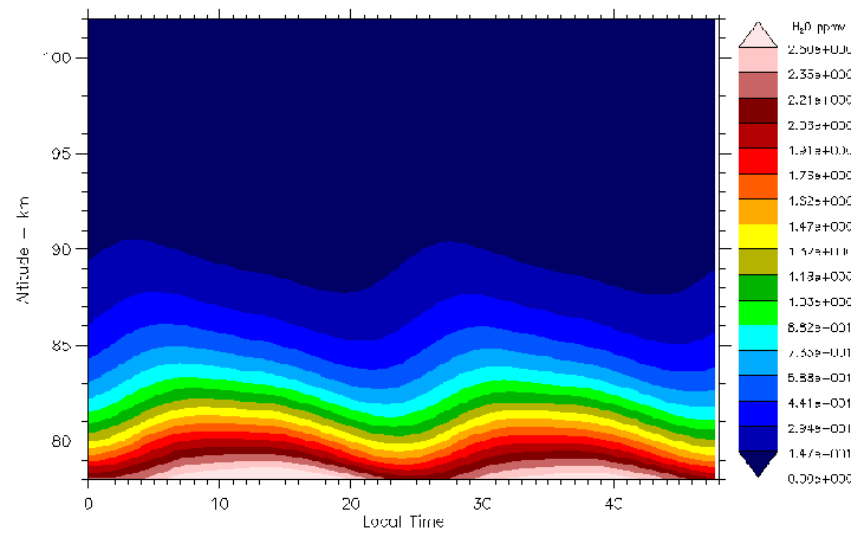

Fig. 1a. $\mathrm{H}_{2} \mathrm{O}$ profiles for model days seven through eight for April equatorial conditions. The model initial conditions are from the ACE-FTS occultation measurements. The effect of the diurnal tide is apparent.

rates are $4 \times 10^{5} \mathrm{~cm}^{2} \mathrm{~s}^{-1}$ and $1 \times 10^{6} \mathrm{~cm}^{2} \mathrm{~s}^{-1}$ for April and August, respectively. The derived background vertical advection in the $90 \mathrm{~km}$ region is upwards at $0.1 \mathrm{~cm} \mathrm{~s}^{-1}$ for April and $0.8 \mathrm{~cm} \mathrm{~s}^{-1}$ for August. This combined effect of eddy diffusion and vertical advection on the measured species profiles is investigated further in a later section.

Since $\mathrm{H}_{2} \mathrm{O}$ is one of the major drivers in uppermesospheric photochemistry, via the catalytic role of odd $\mathrm{H}$, a more detailed discussion of the MSAO begins here with model simulations of $\mathrm{H}_{2} \mathrm{O}$ profiles for April nearequinox conditions (Fig. 1a) and August near-solstice conditions (Fig. 1b). Note the change in scale between Fig. 1a and $b$, and likewise for subsequent figure pairs. For the model $\mathrm{H}_{2} \mathrm{O}$ initial conditions the average of sunrise and sunset ACE-FTS profiles is assumed. This is commensurate with numerical integration beginning at local noon in the model. Time-dependent solutions for the $\mathrm{H}_{2} \mathrm{O}$ profiles include all dynamical terms and relevant photochemical reactions. As discussed later, differences between ACE-FTS sunrise and sunset $\mathrm{H}_{2} \mathrm{O}$ profiles are apparent, a clear manifestation of the diurnal tidal effect. The model solutions in Fig. 1a and $\mathrm{b}$ likewise clearly show the diurnal tidal effect. The steep drop in the April $\mathrm{H}_{2} \mathrm{O}$ mixing ratio from $80 \mathrm{~km}$ to $90 \mathrm{~km}$ is very pronounced compared with the August profile. This difference is one of the indicators for seasonal changes in upper-mesospheric dynamics.

From these $\mathrm{H}_{2} \mathrm{O}$ profiles come the model $\mathrm{H}$ profiles shown in Fig. 2a for April and b for August. The April $\mathrm{H}$ densities are approximately two-thirds the August values over most of the altitude region. From 88 to $100 \mathrm{~km}$ the $\mathrm{H}$ mixing ratio is approximately constant, in agreement with model calculations by Sonnemann and Körner (2003), so reducing the signature of the diurnal tide. Around $85 \mathrm{~km}$, where the $\mathrm{H}$ mixing ratio does change appreciably with altitude, the $\mathrm{H}$ density exhibits a diurnal tidal effect with maximum $\mathrm{H}$ values occurring

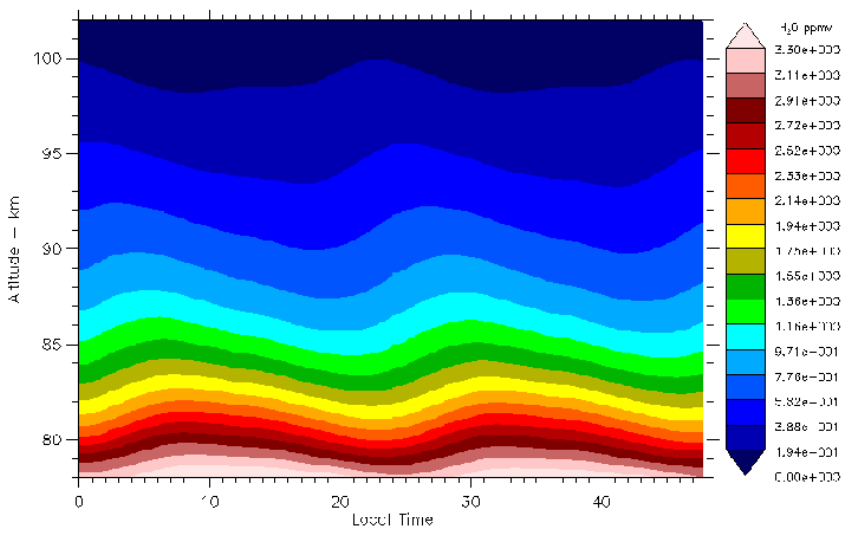

Fig. 1b. $\mathrm{H}_{2} \mathrm{O}$ profiles for model days seven through eight for August equatorial conditions. Note the scale is 1.32 times larger than in Fig. 1a. The August $90 \mathrm{~km} \mathrm{H}_{2} \mathrm{O}$ mixing ratio is approximately five times larger than for April.

several hours after ground-level sunset. Below $80 \mathrm{~km}$ the $\mathrm{H}$ density is driven primarily by photochemistry, with the density increasing in the afternoon hours, thus replacing the loss of odd $\mathrm{H}$ species that occurred during the previous night.

The model O profiles for April are shown in Fig. 3a and for August in Fig. 3b. The maximum O densities for August are approximately one-half those for April. The diurnal tides are again apparent. Above $100 \mathrm{~km}$ the effects of the semi-diurnal tides, also included in the 1-D model simulation, are readily seen.

Model $\mathrm{O}_{3}$ profiles for April are shown in Fig. 4a and for August in b. Again the diurnal tides are obviously present, but are more complex than for $\mathrm{O}$ as a result of the strong temperature dependence of the $\mathrm{O} / \mathrm{O}_{3}$ partitioning. The temperature minimum, which occurs near 05:00 local time (LT), results in an increase in the $\mathrm{O}_{3}$ density relative to $\mathrm{O}$. The maximum model $\mathrm{O}_{3}$ densities for August are less than onehalf those for April.

The results for $\mathrm{H}_{2} \mathrm{O}, \mathrm{H}, \mathrm{O}$ and $\mathrm{O}_{3}$, in Fig. 1 through 4 are compared in a later section with the MSAO observations. However, since the comparisons with observations are tied to the specific local times of the observations from multiple satellites, the diurnal tides are discussed first. The impact of the diurnal tides can be significant, especially in the upper mesosphere and lower thermosphere. In addition the phase of the tides is altitude dependent, which further complicates comparisons involving multiple species.

\section{Checking the model diurnal tides}

The diurnal variation of $\mathrm{O}$ shown in Fig. 3a for April conditions and in Fig. 3b for August conditions provides an opportunity to check the validity of the simulated tides. The local time phases of the model $\mathrm{O}$ tides as a function of altitude can be compared with the diurnal variations described by 


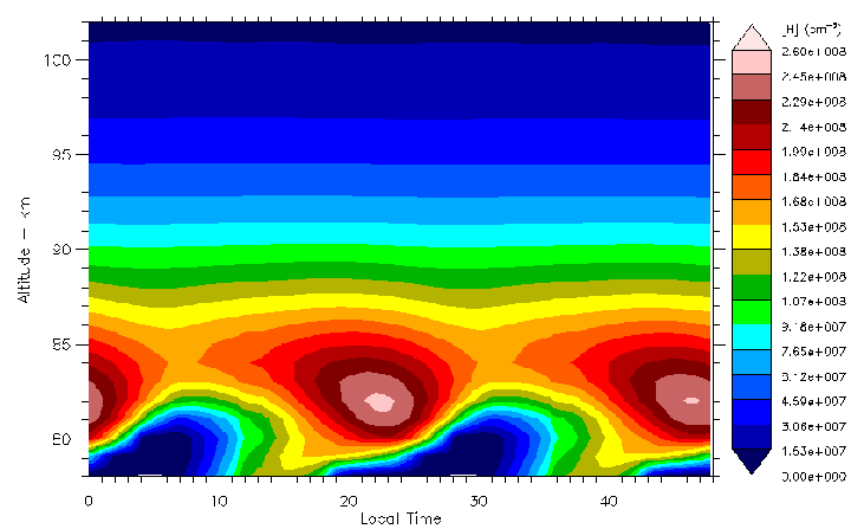

Fig. 2a. Simulated $\mathrm{H}$ for model days seven through eight for April at the Equator. The dominant determining factors are the $\mathrm{H}_{2} \mathrm{O}$ mixing ratio, from the ACE-FTS measurements, and the Lyman- $\alpha$ flux from the SORCE dataset.

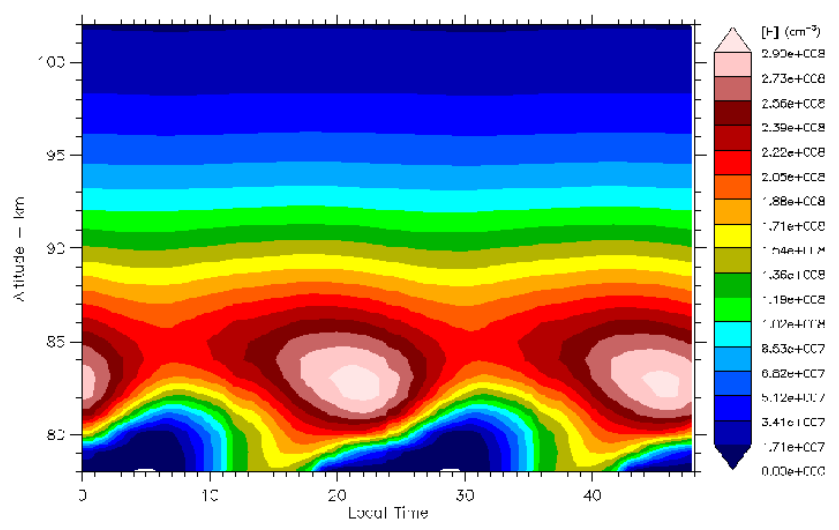

Fig. 2b. Model $\mathrm{H}$ for model days seven through eight for August at the Equator. Note the scale is 1.12 times larger than in Fig. 2a. From 85 to $90 \mathrm{~km}$ the April $\mathrm{H}$ values are approximately two-thirds the August values.

Smith et al. (2010) for O derived from the SABER observations. Beginning at $82 \mathrm{~km}$, for equatorial vernal equinox, the O maximum from SABER data occurs between 23:00 LT and 02:00 LT (their Fig. 3), while for the current model it occurs between 21:00 LT and 01:00 LT (Fig. 3a). Switching to the $\mathrm{O}$ minimum SABER results show that it is at $94 \mathrm{~km}$ between 00:00 LT and 04:00 LT (their Fig. 4), while from Fig. 3a the minimum at $94 \mathrm{~km}$ is between 00:00 LT and 03:00 LT. Similarly, the equatorial $\mathrm{O}$ tides derived from the UARS/WINDII observations by Russell et al. (2005) show a maximum at $82 \mathrm{~km}$ between 20:00 LT and 01:00 LT (their Fig. 8) and a minimum at $94 \mathrm{~km}$ between 00:00 LT and 05:00 LT (their Fig. 8). The agreement between the model and the observations is within 02:00 LT.

The effects of diurnal tides are also clearly seen in the ACE-FTS sunrise versus sunset profiles for $\mathrm{H}_{2} \mathrm{O}$ and for $\mathrm{CO}$ (Fig. 5a). These species show a marked change in mixing

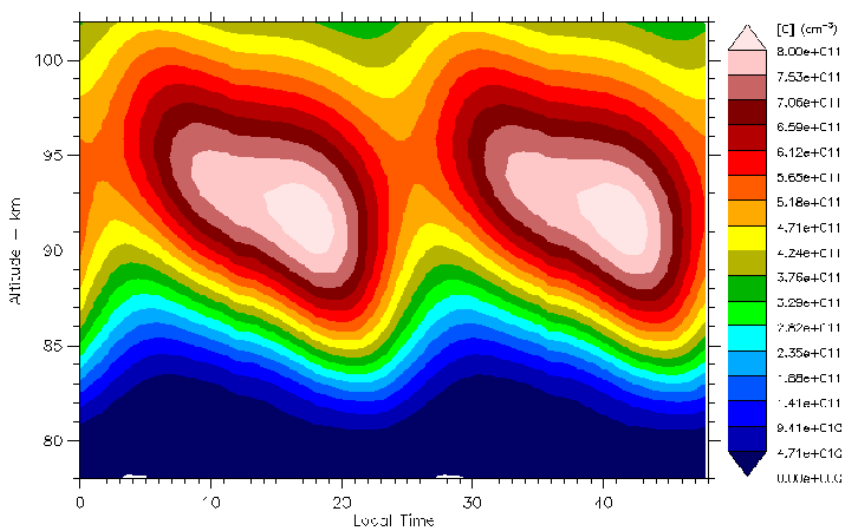

Fig. 3a. Local time variation of $\mathrm{O}$ for model days seven through eight in the April equatorial region. The effects of the diurnal tides are evident. The tidal phases compare well with the SABER O observations by Smith et al. (2010) and Russell et al. (2005).

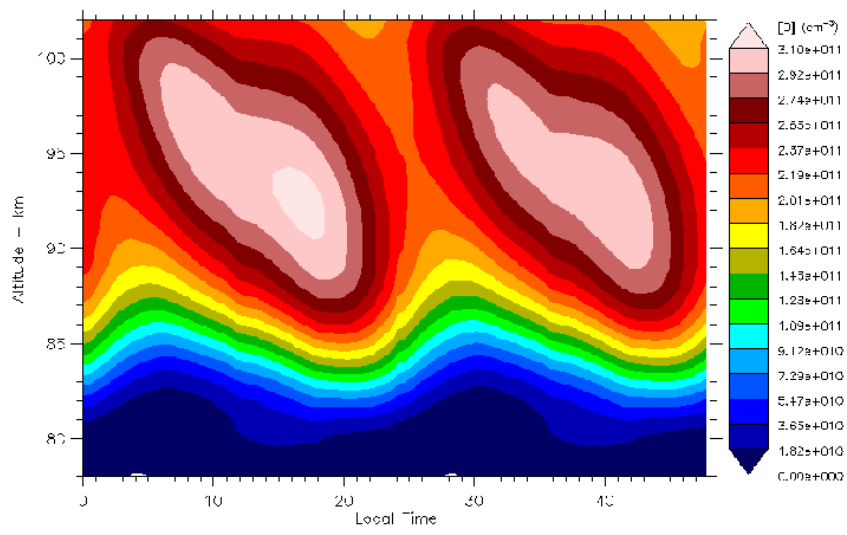

Fig. 3b. Local time variation of $\mathrm{O}$ for model days seven through eight in the equatorial region for August. The effects of the diurnal tides are again evident. Note the scale is 2.28 times smaller than in Fig. 3a. The maximum $\mathrm{O}$ densities are less than one-half those for April in Fig. 3a.

ratio with altitude in the upper mesosphere and are consequently sensitive to the altitude shift caused by diurnal tides. Hence, these observed diurnal changes afford a further opportunity to validate the simulation of the diurnal tides. The model $\mathrm{H}_{2} \mathrm{O}$ tides in Fig. 1a are out of phase with the model $\mathrm{CO}$ tides in Fig. 5b. This is expected since in the $90 \mathrm{~km}$ region the $\mathrm{H}_{2} \mathrm{O}$ mixing ratio decreases with increasing altitude, while the $\mathrm{CO}$ mixing ratio increases with altitude. The phases of the model tides in Fig. 1a and b are in approximate agreement with those of Fig. 5a. With the phases of the model tides appearing to be valid, comparisons using local-time-dependent observations of the MSAO are discussed in the next section. 


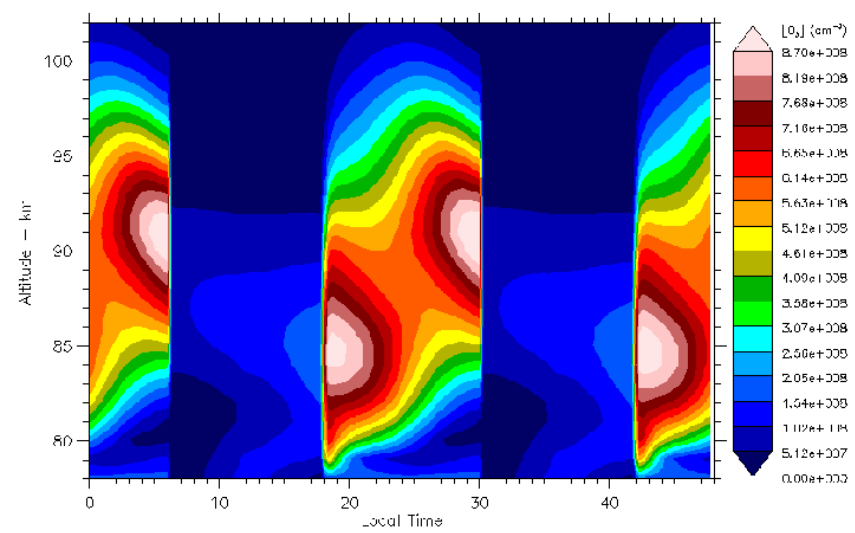

Fig. 4a. Local time variation of $\mathrm{O}_{3}$ for model days seven through eight in the equatorial region for April. The effects of the diurnal tides are again evident. The large increase in $\mathrm{O}_{3}$ just before sunrise is co-located with the diurnal temperature minimum and indicates the change in the $\mathrm{O}$ and $\mathrm{O}_{3}$ partitioning with temperature.

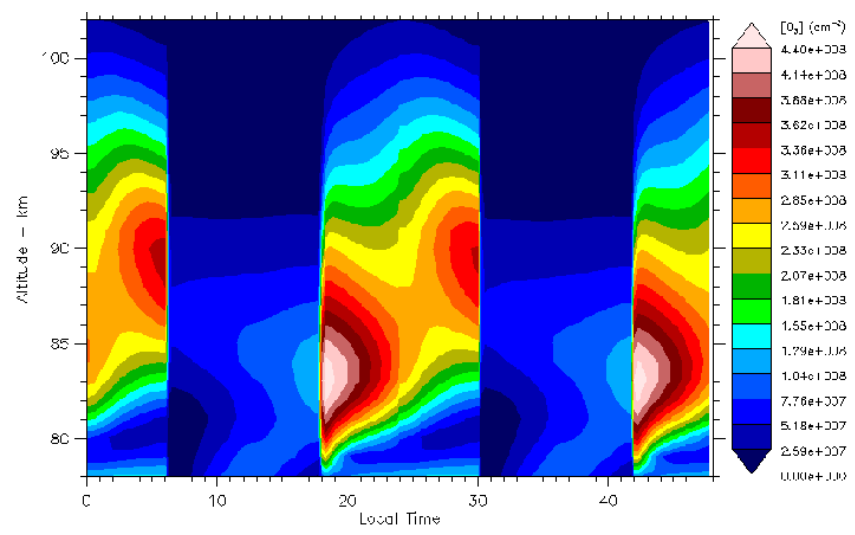

Fig. 4b. Local time variation of $\mathrm{O}_{3}$ for model days seven through eight in the equatorial region for August. The effects of the diurnal tides are again evident. Note the scale is 1.98 times smaller than in Fig. 4a. The August $\mathrm{O}_{3}$ densities are approximately one-third the April densities.

\section{MSAO - model versus observations}

A persistent MSAO was observed in the nighttime $\mathrm{O}_{3}$ density by Kyrölä et al. (2010) using the GOMOS instrument on the Envisat satellite. The multi-year observations, extending from 2002 through 2008, exhibit a dominant semi-annual component at $90 \mathrm{~km}$ at the Equator (Fig. 6). The maximum $\mathrm{O}_{3}$ densities, about $6 \times 10^{8} \mathrm{~cm}^{-3}$, occur just after equinox periods, while the minimum densities, about $2 \times 10^{8} \mathrm{~cm}^{-3}$, occur just after the solstice periods. The nighttime measurements are between 21:00 LT and 24:00 LT, determined by the Envisat constant local time orbit. The individual $\mathrm{O}_{3}$ density profiles extend up to approximately $100 \mathrm{~km}$ and clearly show the secondary peak near $90 \mathrm{~km}$. The quasi-biennial oscillations noted by Shepherd et al. (2006) are not immedi-

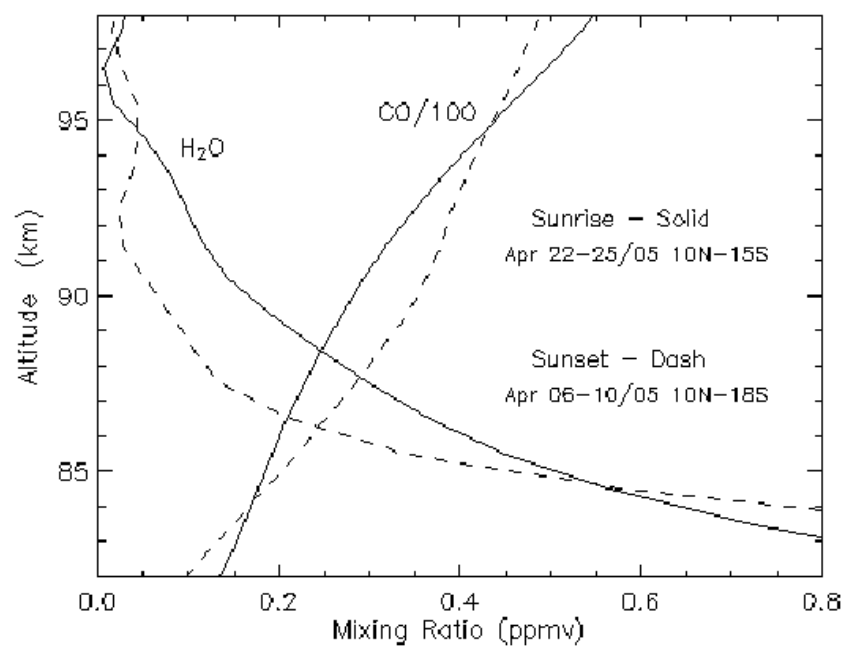

Fig. 5a. ACE-FTS mixing ratio observations for April 2005 sunrise and sunset at the Equator showing the effects of the diurnal tides on $\mathrm{CO}$ and $\mathrm{H}_{2} \mathrm{O}$. The tides are out of phase, as expected, since the changes in mixing ratio profiles with altitude are of opposite sign.

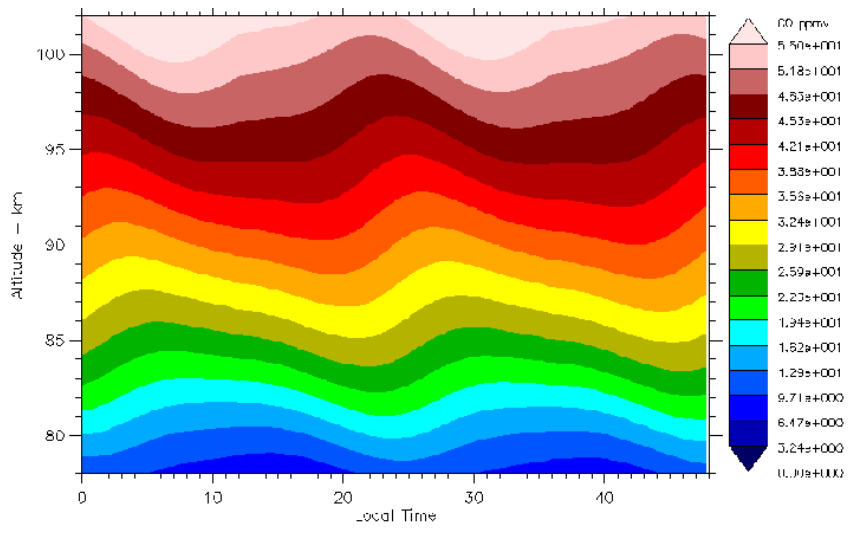

Fig. 5b. Model diurnal tide for CO for April, days seven through eight, for comparison with the ACE-FTS sunrise/sunset observations. At $90 \mathrm{~km}$ altitude the sunrise mixing ratio is smaller than the sunset mixing ratio, as in Fig. 5a.

ately apparent in the GOMOS $\mathrm{O}_{3}$ observations in the equatorial region. Huang et al. (2008), using the SABER instrument on the TIMED satellite, also observed a strong seasonal variation in $\mathrm{O}_{3}$ at $90 \mathrm{~km}$ at the Equator. However, their maximum $\mathrm{O}_{3}$ viewing altitude is limited to approximately $90 \mathrm{~km}$, and thus they do not delineate a secondary $\mathrm{O}_{3}$ density peak as definitively.

Ozone densities from the model simulations for April and for August are shown as the large squares in Fig. 6. These simulated densities are for the final derived eddy diffusion rates and background vertical advection rates indicated in the previous section.

A further comparison is included here, this one between model $\mathrm{OH}^{*}$ and OSIRIS spectral observations of the MSAO 


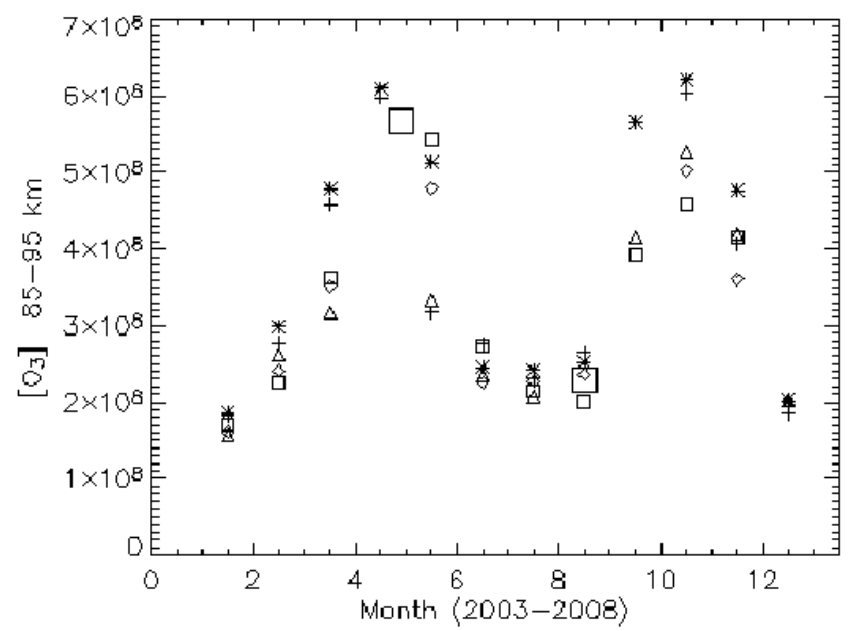

Fig. 6. The mesospheric semi-annual oscillation of $\mathrm{O}_{3}$ density observed by the GOMOS instrument for nighttime conditions is shown. Monthly averages are included where available for years from 2003 to 2008. The two large squares indicate the model $\mathrm{O}_{3}$ densities for April "near-equinox" and August "near-solstice" conditions for approximately 23:00 LT with eddy diffusion and background vertical winds derived from the model. Symbols for 2003 to 2008, respectively: plus sign, asterisk, period, diamond, triangle, and square.

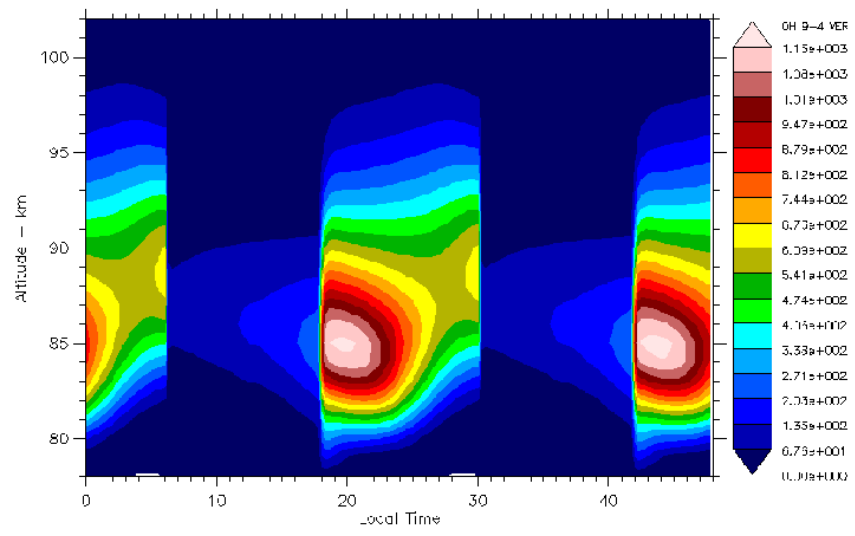

Fig. 7a. Model $\mathrm{OH}^{*}$ 9-4 volume emission rates for April, days seven through eight, from model $\left[\mathrm{O}_{3}\right]$ and $(\mathrm{H})$ values. Rates are from Adler-Golden (1997). VER units are in photons $\mathrm{cm}^{-3} \mathrm{~s}^{-1}$.

for the $\mathrm{OH}^{*}$ 9-4 Meinel emission band. Model volume emission rate (VER) profiles of $\mathrm{OH}^{*}$ 9-4 band total are shown for April in Fig. 7a and for August in Fig. 7b. The $\mathrm{OH}^{*}$ product is determined from the model $\mathrm{H}$ and $\mathrm{O}_{3}$ profiles. The $\mathrm{OH}^{*}(v \prime=9)$ nascent band fractional production (0.47) and the deactivation rates for $\mathrm{O}_{2}, \mathrm{~N}_{2}$ and $\mathrm{O}$ are from Adler-Golden (1997). $\mathrm{OH}^{*}$ rotational line transition probabilities are from the tabulations by van der Loo and Groenenboom $(2007,2008)$. The seasonal variation of $\mathrm{OH}^{*}$ 9-4 obtained from the OSIRIS spectra observations is shown in Figure 8. Limb observations were converted to volume

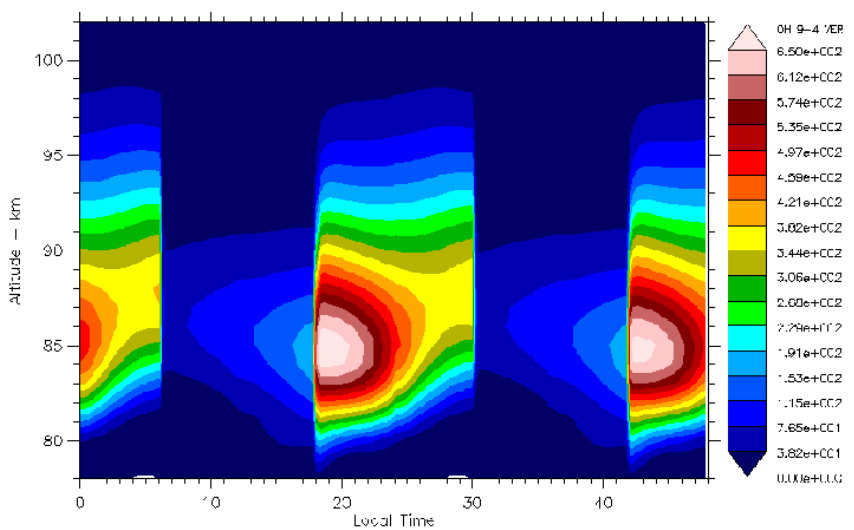

Fig. 7b. Model $\mathrm{OH}^{*}$ 9-4 volume emission rates for August, days seven through eight, from model $\left[\mathrm{O}_{3}\right]$ and $(\mathrm{H})$ values. Note the scale is 1.77 times smaller than in Fig. 7a. VER units are in photons $\mathrm{cm}^{-3} \mathrm{~s}^{-1}$.

emission rate vertical profiles and then summed vertically to provide a reference to zenith observations. From the tabulations of Cosby and Slanger (2007) the observed $\mathrm{OH}^{*}$ 9-4 brightness varies from approximately 300 to 900 rayleighs $\left(1 \mathrm{R}=10^{6}\right.$ photons $\left.\mathrm{cm}^{-2} \mathrm{~s}^{-1}\right)$, without regard for time and location. The two large square symbols in Fig. 8 indicate the model emission for April and for August at approximately 20:00 LT, which corresponds with the OSIRIS low-latitude observations. Both model and observation show a decreased $\mathrm{OH}^{*}$ from April to August although the ratios are different. Slightly better agreement is achieved by arbitrarily increasing the rate of removal of $\mathrm{OH}^{*}(v \prime=9)$ by $\mathrm{O}$ by a factor of three (diamond symbols). As noted by Adler-Golden (1997) this rate is very uncertain. However, Smith et al. (2010) concluded that the collision rate with $\mathrm{O}$ must be reduced to satisfy the SABER O density measurements.

Some portion of the equatorial MSAO can arise from the seasonal variation of solar insolation. Model calculations indicate that in the $85-95 \mathrm{~km}$ region the April-August change in the photodissociation rate of $\mathrm{O}_{2}$ averaged over $24 \mathrm{~h}$ is less than $5 \%$. Similarly, seasonal changes in temperature can influence the $\mathrm{O}-$ to- $\mathrm{O}_{3}$ ratio, and so impact the comparison here with the GOMOS $\mathrm{O}_{3}$ observations. Model simulations for the local time of the GOMOS observations, approximately $23 \mathrm{~h}$, again yield an April-August change of less than $5 \%$ in the $85-95 \mathrm{~km}$ region.

\section{Interactions between vertical eddy diffusion and vertical advection}

The model results presented above, using August as an example for this discussion, are for the calculated eddy diffusion rates of $1 \times 10^{6} \mathrm{~cm}^{2} \mathrm{~s}^{-1}$ at $90 \mathrm{~km}$ altitude and for a vertical advection of $0.8 \mathrm{~cm} \mathrm{~s}^{-1}$. The impact of arbitrarily varying these two parameters is shown in Fig. 9. A grid 


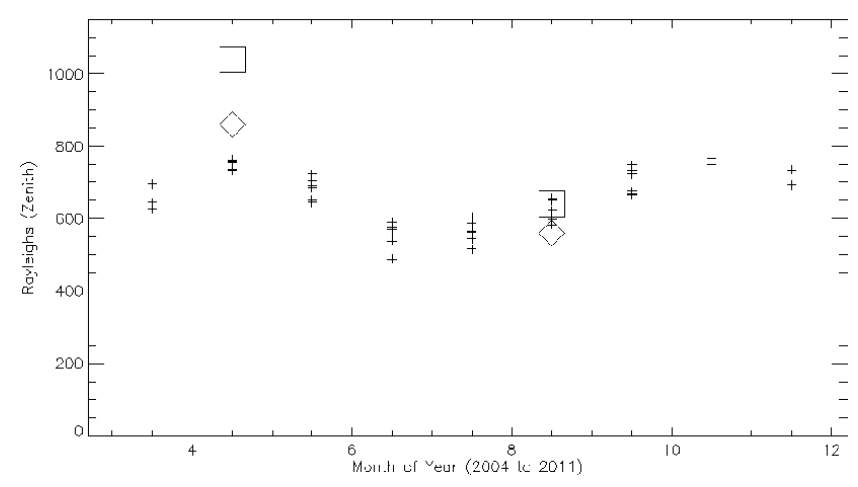

Fig. 8. Monthly averages of the $\mathrm{OH}^{*} 9-4$ brightness, referred to zenith viewing, as observed by OSIRIS in the equatorial region from 2004 to 2011 (plus signs). The April and August model OH* 9-4 brightness with rates from Adler-Golden (1997) are given by the square symbols. The diamond symbols are with the rate for $\mathrm{OH}^{*}$ $\left(v^{\prime}=9\right)$ removal by $\mathrm{O}$ arbitrarily scaled up by 3 , near gas kinetic.

of model solutions was generated with the eddy diffusion rates arbitrarily increased, and decreased, by a factor of two, and for the vertical advection increased, and decreased, by $0.2 \mathrm{~cm} \mathrm{~s}^{-1}$. Reducing the eddy diffusion rate causes a decrease in the $\mathrm{H}_{2} \mathrm{O}$ mixing ratio at $90 \mathrm{~km}$ - the result of the ongoing loss of water vapour by Lyman- $\alpha$ photodissociation - and also decreases the $\mathrm{O}_{3}$ density, with less $\mathrm{O}$ being mixed downwards. Increasing the vertical advection increases the $\mathrm{H}_{2} \mathrm{O}$ mixing ratio at $90 \mathrm{~km}$ by moving $\mathrm{H}_{2} \mathrm{O}$-rich air upwards and decreases $\mathrm{O}_{3}$ by moving $\mathrm{O}$ deficient air upwards. The measured $\mathrm{H}_{2} \mathrm{O}$ mixing ratio and $\mathrm{O}_{3}$ density are indicated by the large square in Fig. 9. The width of the square is defined by the estimated $\mathrm{H}_{2} \mathrm{O}$ measurement precision over the equatorial region and the height by that for $\mathrm{O}_{3}$.

The final values for eddy diffusion and for vertical advection come close to simultaneously matching the measured $\mathrm{H}_{2} \mathrm{O}$ mixing ratio and $\mathrm{O}_{3}$ density. However, the model solution diverges rapidly when either of these two parameters is changed. Based on the estimated measurement precision it would appear that, using the approach described here, the vertical advection can be determined to within $0.1 \mathrm{~cm} \mathrm{~s}^{-1}$ and the eddy diffusion rate to within $2 \times 10^{5} \mathrm{~cm}^{2} \mathrm{~s}^{-1}$.

These simulations suggest that dynamical effects including vertical advection and eddy diffusion are implicitly involved in the generation of the MSAO. Exactly how they are related to gravity wave momentum as discussed by Dunkerton (1982) three decades ago remains to be addressed.

\section{Conclusions}

Observational data from a number of sources have been assembled to investigate the equatorial MSAO with the aid of a 1-D photochemical model that includes diurnal tides, vertical advection and eddy diffusion. The diurnal tides included in

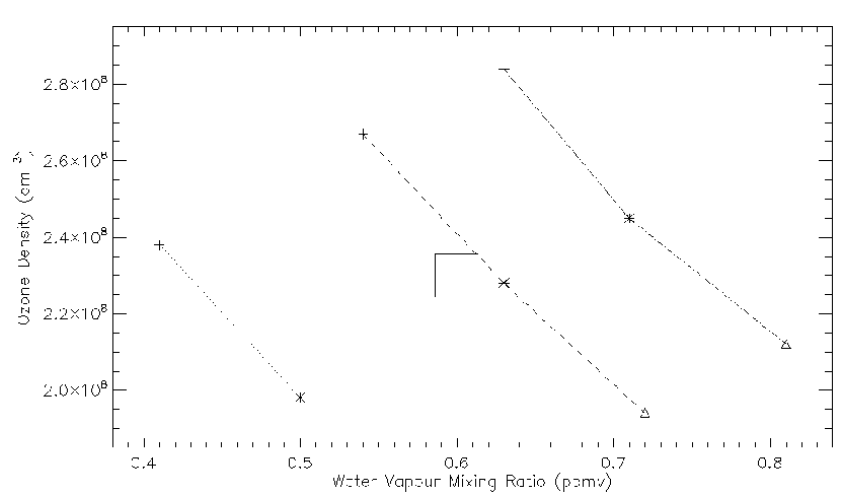

Fig. 9. The relationship between the combined effects of assumed eddy diffusion rates and vertical advection and the model $\mathrm{O}_{3}$ density and $\mathrm{H}_{2} \mathrm{O}$ mixing ratio at an altitude of $90 \mathrm{~km}$ in August. The large square locates the $\mathrm{H}_{2} \mathrm{O}$ mixing ratio measured by ACE-FTS and the $\mathrm{O}_{3}$ density measured by GOMOS (see text). Plus signs are for an assumed vertical advection of $0.6 \mathrm{~cm} \mathrm{~s}^{-1}$, asterisks for $0.8 \mathrm{~cm} \mathrm{~s}^{-1}$ and triangles for $1.0 \mathrm{~cm} \mathrm{~s}^{-1}$. The dotted line is for an assumed eddy diffusion rate of approximately $5 \times 10^{5} \mathrm{~cm}^{2} \mathrm{~s}^{-1}$, the dashed line for $1.0 \times 10^{6} \mathrm{~cm}^{2} \mathrm{~s}^{-1}$ and the dot-dash line for $2 \times 10^{6} \mathrm{~cm}^{2} \mathrm{~s}^{-1}$. On this grid of model simulations the closest match to the observations is for a calculated eddy diffusion rate of $1 \times 10^{6} \mathrm{~cm}^{2} \mathrm{~s}^{-1}$ and a vertical advection of $0.8 \mathrm{~cm} \mathrm{~s}^{-1}$.

the simulation have been verified by comparison with a number of observed tidal signatures, in particular $\mathrm{O}, \mathrm{H}_{2} \mathrm{O}$ and $\mathrm{CO}$ diurnal variations. The two key measured parameters are the $\mathrm{H}_{2} \mathrm{O}$ mixing ratio and the $\mathrm{O}_{3}$ density. From the ACE-FTS observations the $\mathrm{H}_{2} \mathrm{O}$ mixing ratio at $90 \mathrm{~km}$ in the equatorial region is observed to increase by a factor of approximately five from April to August. From the GOMOS observations the $\mathrm{O}_{3}$ density at $90 \mathrm{~km}$ at the Equator is found to decrease by approximately a factor of three from April to August.

The 1-D model is also used to investigate the impact of these observed seasonal variations. The analysis suggests that by constraining the model with the measured input parameters, namely the $\mathrm{H}_{2} \mathrm{O}$ mixing ratio and the $\mathrm{O}_{3}$ density, it is possible to derive unique values for the vertical advection rate and the eddy diffusion rate. For August, at the Equator and $90 \mathrm{~km}$ altitude, an eddy diffusion rate of approximately $1 \times 10^{6} \mathrm{~cm}^{2} \mathrm{~s}^{-1}$ and vertical advection of approximately $0.8 \mathrm{~cm} \mathrm{~s}^{-1}$ are inferred from the 1-D model. For April the corresponding values are approximately $4 \times 10^{5} \mathrm{~cm}^{2} \mathrm{~s}^{-1}$ and $0.1 \mathrm{~cm} \mathrm{~s}^{-1}$. Even though the 1-D model solution here is limited in scope, the uncertainty in the derived eddy diffusion rates is estimated to be less than $2 \times 10^{5} \mathrm{~cm}^{2} \mathrm{~s}^{-1}$ and in vertical advection to be less than $0.1 \mathrm{~cm} \mathrm{~s}^{-1}$. Assuming this approach to inferring mesopause dynamics withstands further testing, the technique will markedly improve the measurement accuracy of vertical advection and eddy diffusion.

As a further check of the model results the simulated $\mathrm{OH}^{*}$ 9-4 band emission, using model $\mathrm{H}$ and $\mathrm{O}_{3}$ densities, was compared with the seasonal variation of the $\mathrm{OH}^{*} 9-4$ band 
observed by OSIRIS. Agreement of the trend in the seasonal variation was satisfactory, while agreement in absolute brightness was poor.

It is apparent that the analysis presented here should be extended to latitudes outside the equatorial region to yield further insights into vertical advection and eddy diffusion. The process would benefit considerably if in future missions all the relevant parameters were measured simultaneously.

Acknowledgements. The Atmospheric Chemistry Experiment (ACE), also known as SCISAT-1, is a Canadian-led mission mainly supported by the Canadian Space Agency and the Natural Sciences and Engineering Research Council of Canada. Odin is a Swedish-led satellite project funded jointly by Sweden (SNSB), Canada (CSA), France (CNES) and Finland (Tekes). GOMOS on board ENVISAT is funded through the European Space Agency. The work of E. Kyrölä was supported by the Academy of Finland through the project MIDAT (\#134325).

Edited by: A. Richter

\section{References}

Adler-Golden, S.: Kinetic parameters for $\mathrm{OH}$ nightglow modeling consistent with recent laboratory experiments, J. Geophys. Res., 102, 19969-19976, doi:10.1029/97JA01622, 1997.

Alexander, M. J., M. Geller, C. McLandress, S. Polavarapu, P. Preusse, F. Sassi, K. Sato, S. Eckermann, M. Ern, A. Hertzog, Y. Kawatani, M. Pulido, T. A. Shaw, M. Sigmond, R. Vincent, and Watanabe, S.: Recent developments in gravity-wave effects in climate models and the global distribution of gravity-wave momentum flux from observations and models, Q. J. R. Meteorol. Soc., 136, 1103-1124, doi:10.1002/qj.637, 2010.

Bernath, P. F., C. T. McElroy, M. C. Abrams, C. D. Boone, M. Butler, C. Camy-Peyret, M. Carleer, C. Clerbaux, P.-F Coheur, R. Colin, P. DeCola, M. De Mazière, J. R. Drummond, D. Dufour, W. F. J. Evans, H. Fast, D. Fussen, K. Gilbert, D. E. Jennings, E. J. Llewellyn, R. P. Lowe, E. Mahieu, J. C. McConnell, M. McHugh, S. D. McLeod, R. Michaud, C. Midwinter, R. Nassar, F. Nichitiu, C. Nowlan, C. P. Rinsland, Y. J. Rochon, N. Rowlands, K. Semeniuk, P. Simon, R. Skelton, J. J. Sloan, M.A. Soucy, K. Strong, P. Tremblay, D. Turnbull, K. A. Walker, I. Walkty, D. A. Wardle, V. Wehrle, R. Sander, and Zou, J.: Atmospheric Chemistry Experiment (ACE): mission overview, Geophys. Res. Lett., 32, L15S01, doi:10.1029/2005GL022386, 2005.

Brasseur, G. P. and Solomon, S.: Aeronomy of the Middle Atmosphere, Springer, Dordrecht, the Netherlands, 2005.

Burrage, M. D., N. Arvin, W. R. Skinner, and Hays, P. B.: Observations of the $\mathrm{O}_{2}$ atmospheric band nightglow by the High Resolution Doppler Imager, J. Geophys. Res., 99, 15017-15023, 1994.

Chabrillat, S. and Kockarts, G.: Simple parameterization of the solar Lyman-alpha line, Geophys. Res. Lett., 24, 2659-2662. 1997.

Chandra, S., C. H. Jackman, E. L. Fleming, and Russell III, J. M.: The seasonal and long term changes in mesospheric water vapor, Geophys. Res. Lett., 24, 639-642, 1997.
Cogger, L. L, R. D. Elphinstone, and Murphree, J. S.: Temporal and latitudinal $5577 \AA$ airglow variations, Can. J. Phys., 59, 12961307, 1981.

Cosby, P. C. and Slanger, T. G.: OH spectroscopy and chemistry investigated with astronomical sky spectra, Can. J. Phys., 85, 7799, 2007.

Dikty, S., Schmidt, H., Weber, M., von Savigny, C., and Mlynczak, M. G.: Daytime ozone and temperature variations in the mesosphere: a comparison between SABER observations and HAMMONIA model, Atmos. Chem. Phys., 10, 8331-8339, doi:10.5194/acp-10-8331-2010, 2010

Dunkerton, T. J.: Theory of the mesopause semiannual oscillation, J. Atmos. Sci., 39, 2682-2690, 1982.

Fauliot, V., Thuillier, G., and Vial, F.: Mean vertical wind in the mesosphere-lower thermosphere region, (80-120 km) deduced from the WINDII observations on board UARS, Ann. Geophys., 15, 1221-1231, 1997, http://www.ann-geophys.net/15/1221/1997/.

Fukuyama, K.: Airglow variations and dynamics in the lower thermosphere and upper mesosphere - II. Seasonal and long-term variations, J. Atmos. Terr. Phys., 39, 1-14, 1977.

Hagan, M. E., M. D. Burrage, J. M. Forbes, J. Hackney, W. J. Randel, and Zhang, X.: GSWM-98: results for migrating solar tides, J. Geophys. Res., 104, 6813-6827, 1999.

Hall, C. M., U.-P. Hoppe, T. A. Blix, E. V. Thrane, A. H. Manson, and Meek, C. E., Seasonal variation of turbulent energy dissipation rates in the polar mesosphere: a comparison of methods, Earth Planets Space, 51, 515-524, 1999.

Holton, J. R.: An introduction to dynamic meteorology, 4th Edn., Elsevier, Burlingotn, MA, 2004.

Huang, F. T., Mayr, H. G., Russell III, J. M., Mlynczak, M. G., and Reber, C. A.: Ozone diurnal variations and mean profiles in the mesosphere, lower thermosphere, and stratosphere, based on measurements from SABER on TIMED, J. Geophys. Res., 113, A04307, doi:10.1029/2007JA012739, 2008.

John, S. R. and Kumar, K. K.: TIMED/SABER observations of global cold point mesopause variability at diurnal and planetary wave scales, J. Geophys. Res., 116, A06314, doi:10.1029/2010JA015945, 2011.

Kockarts, G.: Penetration of solar radiation in the Schumann-Runge bands of molecular oxygen: a robust approximation, Ann. Geophys., 12, 1207-1217, 1994,

http://www.ann-geophys.net/12/1207/1994/.

Kyrölä, E., J. Tamminen, G. L. Leppelmeier, V. Sofieva, S. Hassinen, A. Seppala, P. T. Verronen, J. L. Bertaux, A. Hauchecorne, F. Dalaudier, D. Fussen, F. Vanhellemont, O. Fanton d'Andon, G. Barrot, A. Mangin, B. Theodore, M. Guirlet, R. Koopman, L. Saavedra de Miguel, P. Snoeij, T. Fehr, Y. Meijer, and Fraisse, R.: Nighttime ozone profiles in the stratosphere and mesosphere by the Global Ozone Monitoring by Occultation of Stars on Envisat, J. Geophys. Res., 111, D24306, doi:10.1029/2006JD007193, 2006.

Kyrölä, E., Tamminen, J., Sofieva, V., Bertaux, J. L., Hauchecorne, A., Dalaudier, F., Fussen, D., Vanhellemont, F., Fanton d'Andon, O., Barrot, G., Guirlet, M., Fehr, T., and Saavedra de Miguel, L.: GOMOS $\mathrm{O}_{3}, \mathrm{NO}_{2}$, and $\mathrm{NO}_{3}$ observations in 2002-2008, Atmos. Chem. Phys., 10, 7723-7738, doi:10.5194/acp-10-77232010, 2010. 
Lewis, B. R., Vardavas, I. M. and Carver, J. H.: The aeronomic dissociation of water vapour by solar Lyman- $\alpha$ radiation, J. Geophys. Res., 88, 4935-4940, 1983.

Llewellyn, E. J., Lloyd, N. D., Degenstein, D. A., Gattinger, R. L., Petelina, S. V., Bourassa, A. E., Wiensz, J. T., Ivanov, E. V., McDade, I. C., Solheim, B. H., McConnell, J. C., Haley, C. S., von Savigny, C., Sioris, C. E., McLinden, C. A., Griffioen, E., Kaminski, J., Evans, W. F. J., Puckrin, E., Strong, K., Wehrle, V., Hum, R. H., Kendall, D. J. W., Matsushita, J., Murtagh, D. P., Brohede, S., Stegman, J., Witt, G., Barnes, G., Payne, W. F., Piché, L., Smith, K., Warshaw, G., Deslauniers, D.-L., Marchand, P., Richardson, E. H., King, R. A., Wevers, I., McCreath, W., Kyrölä, E., Oikarinen, L., Leppelmeier, G. W., Auvinen, H., Mégie, G., Hauchecorne, A., Lefèvre, F., de La Nöe, J., Ricaud, P., Frisk, U., Sjoberg, F., von Schéele, F. and Nordh, L.: The OSIRIS Instrument on the Odin Spacecraft, Can. J. Phys., 82, 411-422, 2004.

Liu, A. Z.: Estimated eddy diffusion coefficients from gravity wave vertical momentum and heat fluxes, Geophys. Res. Lett., 36, L08806, doi:10.1029/2009GL037495, 2009.

Lossow, S., Urban, J., Gumbel, J., Eriksson, P., and Murtagh, D.: Observations of the mesospheric semi-annual oscillation (MSAO) in water vapour by Odin/SMR, Atmos. Chem. Phys., 8, 6527-6540, doi:10.5194/acp-8-6527-2008, 2008.

Marsh, D., Smith, A., and Noble, E.: Mesospheric ozone response to changes in water vapor, J. Geophys. Res., 108, 4109, doi:10.1029/2002JD002705, 2003.

McCormack, J. P., Hoppel, K. W., and Siskind, D. E.: Parameterization of middle atmospheric water vapor photochemistry for high-altitude NWP and data assimilation, Atmos. Chem. Phys., 8, 7519-7532, doi:10.5194/acp-8-7519-2008, 2008.

McDade, I. C., Murtagh, D. P., Greer, R. G. H., Dickinson, P. H. G., Witt, G., Stegman, J., Llewellyn, E. J., Thomas, L., and Jenkins, D. B.: ETON 2: Quenching parameters for the proposed precursors of $\mathrm{O}_{2}\left(\mathrm{~b}^{1} \Sigma_{g}^{+}\right)$and $\left.\mathrm{O}^{1} \mathrm{~S}\right)$ in the terrestrial nightglow, Planet. Space Sci., 34, 789-800, 1986.

Murtagh, D., Frisk, U., Merino, F., Ridal, M., Jonsson, A., Stegman, J., Witt, G., Eriksson, P., Jiménez, C., Megie, G., de la Noë, J., Ricaud, P., Baron, P., Pardo, J. R., Hauchecorne, A., Llewellyn, E. J., Degenstein, D. A., Gattinger, R. L., Lloyd, N. D., Evans, W. F. J., McDade, I. C., Haley, C. S., Sioris, C., von Savigny, C., Solheim, B. H., McConnell, J. C., Strong, K., Richardson, E. H., Leppelmeier, G. W., Kyrölä, E., Auvinen, H., and Oikarinen, L.: An overview of the Odin atmospheric mission, Can. J. Phys., 80, 309-319, 2002.

Picone, J. M., Hedin, A. E., Drob, D. P., and Aikin, A. C.: NRLMSISE-00 Empirical Model of the Atmosphere: Statistical Comparisons and Scientific Issues, J. Geophys. Res., 107, 1468, doi:10.1029/2002JA009430, 2002.

Portnyagin, Yu. I., Solov'eva, T. V., Merzlyakov, E. G., Pogorel'tsev, A. I., and Savenkova, E. N.: Height-Latitude Structure of the Vertical Wind in the Upper Mesosphere and Lower Thermosphere (70-110 km), J. Atmos. Oceanic Phys., 46, 8594, doi:10.1134/S0001433810010123, 2010.

Qian, L., Solomon, S. C., and Kane, T. J.: Seasonal variation of thermospheric density and composition, J. Geophys. Res., 114, A01312, doi:10.1029/2008JA013643, 2009.

Richter, J. H. and Garcia, R. R.: On the forcing of the Mesospheric Semi-Annual Oscillation in the Whole Atmosphere
Community Climate Model, Geophys. Res. Lett., 33, L01806, doi:10.1029/2005GL024378, 2006.

Richter, J. H., Sassi, F., Garcia, R. R., Matthes, K., and Fischer, C. A.: Dynamics of the middle atmosphere as simulated by the Whole Atmosphere Community Climate Model, version 3 (WACCM3), J. Geophys. Res., 113, D08101, doi:10.1029/2007JD009269, 2008.

Russell, J. P., Ward, W. E., Lowe, R. P., Roble, R. G., Shepherd, G. G. and Solheim, B.: Atomic oxygen profiles $(80-115 \mathrm{~km})$ derived from WIND Imaging Interferometer/Upper Atmosphere Research Satellite measurements of the hydroxyl and greenline airglow: Local time-latitude dependence, J. Geophys. Res., 110, D15306, doi:10.1029/2004JD005570, 2005.

Sander, S. P., Friedl, R. R., Abbatt, J. P. D., Barker, J. R., Burkholder, J. B., Golden, D. M., Kolb, C. E., Kurylo, M. J., Moortgat, G. K., Wine, P. H., Huie, R. E., and Orkin, V. L.: Chemical Kinetics and Photochemical Data for Use in Atmospheric Studies, JPL Publication 10-6, Evaluation Number 17, 2011.

Sasi, M. N. and Vijayan, L.: Turbulence characteristics in the tropical mesosphere as obtained by MST radar at Gadanki $\left(13.5^{\circ} \mathrm{N}\right.$, 79.2E), Annals. Geophys., 19, 1019-1025, 2001.

Shapiro, A. V., Rozanov, E., Shapiro, A. I., Wang, S., Egorova, T., Schmutz, W., and Peter, T.: Signature of the 27-day solar rotation cycle in mesospheric $\mathrm{OH}$ and $\mathrm{H}_{2} \mathrm{O}$ observed by the Aura Microwave Limb Sounder, Atmos. Chem. Phys., 12, 3181-3188, doi:10.5194/acp-12-3181-2012, 2012.

Sharp, W. E. and Kita, D.: In Situ Measurement of Atomic Hydrogen in the Upper Mesosphere, J. Geophys. Res., 92, 4319-4324, 1987.

Sheese, P. E., McDade, I. C., Gattinger, R. L., and Llewellyn, E. J.: Atomic oxygen densities retrieved from Optical Spectrograph and Infrared Imaging System observations of $\mathrm{O}_{2} \mathrm{~A}$-band airglow emission in the mesosphere and lower thermosphere, J. Geophys. Res., 116, D01303, doi:10.1029/2010JD014640, 2011.

Shepherd, M. G., Liu, G., and Shepherd, G. G.: Mesospheric semiannual oscillation in temperature and nightglow emission, J. Atmos. Solar Terr. Phys., 68, 379-389, 2006.

Skinner, W. R., Yee, J. H., Hays, P. B., and Burrage, M. D.: Seasonal and local time variations in the $\mathrm{O}\left({ }^{1} \mathrm{~S}\right)$ green line, $\mathrm{O}_{2}$ atmospheric band and $\mathrm{OH}$ Meinel band emissions as measured by the High Resolution Doppler Imager, Adv. Space Res., 21, 835-841, 1998.

Smith, A. K.: Physics and chemistry of the mesopause region, J. Atmos. Solar Terr. Phys., 66, 839-857, 2004.

Smith, A. K. and Marsh, D. R.: Processes that account for the ozone maximum at the mesopause, J. Geophys. Res., 110, D23305, doi:10.1029/2005JD006298, 2005.

Smith, A. K., Marsh, D. R., Russell III, J. M., Mlynczak, M. G., Martin-Torres, F. J., and Kyrölä, E.: Satellite observations of high nighttime ozone at the equatorial mesopause, J. Geophys. Res., 113, D17312, doi:10.1029/2008JD010066, 2008.

Smith, A. K., Marsh, D. R., Mlynczak, M. G., and Mast, J. C.: Temporal variations of atomic oxygen in the upper mesosphere from SABER, J. Geophys. Res., 115, D18309, doi:10.1029/2009JD013434, 2010.

Sonnemann, G. R. and Körner, U.: Total hydrogen mixing ratio anomaly around the mesopause region, J. Geophys. Res., 108, 4692, doi:10.1029/2002JD003015, 2003. 
Thomas, R. J.: Seasonal Ozone Variations in the Upper Mesosphere, J. Geophys. Res., 95, 7395-7401, 1990.

Thomas, R. J.: Atomic Hydrogen and Atomic Oxygen Density in the Mesopause Region: Global and Seasonal Variations Deduced From Solar Mesosphere Explorer Near-Infrared Emissions, J. Geophys. Res., 95, 16457-16476, 1995.

Tian, F., Kasting, J. F., Liu, H.-L., and Roble, R. G.: Hydrodynamic planetary thermosphere model: 1 . Response of the Earth's thermosphere to extreme EUV conditions and the significance of adiabatic cooling, J. Geophys. Res., 113, E05008, doi:10.1029/2007JE002946, 2008.

Van der Loo, M. P. J. and Groenenboom, G. C.: Theoretical transition probabilities for the $\mathrm{OH}$ Meinel system, J. Chem. Phys., 126, 114314-114317, 2007.

Van der Loo, M. P. J. and Groenenboom, G. C.: Erratum: "Theoretical transition probabilities for the $\mathrm{OH}$ Meinel system" [J. Chem. Phys. 126, 114314, 2007], J. Chem. Phys., 128, 1599012, doi:10.1063/1.2899016, 2008.

Vlasov, M. N. and M. C. Kelley: Estimates of eddy turbulence consistent with seasonal variations of atomic oxygen and its possible role in the seasonal cycle of mesopause temperature, Ann. Geophys., 28, 2103-2110, doi:10.5194/angeo-28-2103-2010, 2010.
Wu, Q., Ortland, D. A., Killeen, T. L., Roble, R. G., Hagan, M. E., Liu, H.-L., Solomon, S. C., Xu, J., Skinner, W. R., and Niciejewski, R. J.: Global distribution and interannual variations of mesospheric and lower thermospheric neutral wind diurnal tide: 1 . Migrating tide, J. Geophys. Res., 113, doi:10.1029/2007JA012542, 2008.

Xu, J., Gao, H., Smith, A. K., and Zhu, Y.: Using TIMED/SABER nightglow observations to investigate hydroxyl emission mechanisms in the mesopause region, J. Geophys. Res., 117, D02301, doi:10.1029/2011JD016342, 2012.

Yee, J.-H., Roble, R. G., Skinner, W. R., Burrage, M. D., and Hays, P. B.: Global simulations and observations of $\mathrm{O}\left({ }^{1} \mathrm{~S}\right), \mathrm{O}_{2}\left({ }^{1} \Sigma\right)$ and OH mesospheric nightglow emissions, J. Geophys. Res., 102, 19949-19968, 1997. 